Nordisk Tidsskrift for Kriminalvidenskab 2011

\title{
FORVARING - FRA SÆRREAKSJON OG "STRAFF" TIL LOVENS STRENGESTE STRAFF: ETT SKRITT FREM ELLER ETT TILBAKE?
}

Av Berit JoHnsen, FOrSKER, KRIMINALOMSORGENS UTDANNINGSSENTER ${ }^{1}$

\begin{abstract}
A new law on preventive detention took effect in Norway January 1st, 2002. Originally preventive detention should serve as both a special criminal sanction and as a 'punishment'.

The essential features of a special criminal sanction are its aim to protect society from those deemed at risk for new serious crimes and the indeterminate length of the sentence. Since the new law took effect the view of preventive detention as a special criminal sanction has disappeared, and it is now considered to be a punishment. Nevertheless, pursuant to the legal provision, the purpose of preventive detention remains individual prevention and incapacitation of those for whom there is a risk of relapse to serious crime. However, the general expectation of proportionality calls for approximately the same length of imprisonment for persons sentenced to preventive detention and those receiving a determinate sentence for a similar crime. Since a sentence to preventive detention can be prolonged, it is now considered the most severe punishment in Norway. This 'new' understanding of preventive detention has led to the dilemmas discussed in the current paper. The central issue is the conflict between the need to protect society via incapacitation and the philosophical demands for proportional sentencing. ${ }^{*}$
\end{abstract}

Noen fakta om forvaring:

- Trådte i kraft 1. januar 2002.

- Pr. 1. januar 2011 var 171 personer blitt dømt til forvaring, hvorav syv var kvinner.

- Pr. 1. januar 2011 satt 76 forvaringsdømte i fengsel.

- Det finnes tre forvaringsanstalter: Ila fengsel og Trondheim fengsel for menn, og Bredveit fengsel for kvinner.

- Pr. 1. januar 2011 hadde 25 personer status som prøveløslatt fra forvaring. Prøveløslatte fra forvaring følges opp av Kriminalomsorg i frihet.

\footnotetext{
* Title in English: Preventive detention: From special sanction and 'punishment' to the law's most severe penalty. Original in Norwegian.
} 
1. januar 2002 ble det gamle sikrings- og forvaringsinstituttet i Norge erstattet av særreaksjonene forvaring, overføring til tvungent psykisk helsevern og overføring til tvungen omsorg. Sikringsinstituttet hadde før den tid vært kritisert i flere tiår, men til tross for den utstrakte kritikken av sikringssystemet tok lovendringene svært lang tid, og det var en del kraftige motsetninger og diskusjoner underveis (se Johnsen 2006). ${ }^{2}$ To utvalg utredet saken - Straffelovrådet $\mathrm{i}$ NOU 1974: 17 Strafferettslig utilregnelighet og strafferettslige scrreaksjoner og Særreaksjonsutvalget i NOU 1990: 5 Strafferettslige utilregnelighetsregler og scerreaksjoner. Likeledes ble lovendringen politisk behandlet i to omganger. ${ }^{3} \mathrm{De}$ store diskusjonene om denne lovreformen har stilnet for lengst, men siden lovbestemmelsen trådte i kraft i 2002 har det skjedd endringer i forståelsen av forvaring sett ut i fra forutsetningene. I disse endringene synes det å ligge noen motsetninger og dilemmaer som jeg ønsker å belyse i denne artikkelen. Først vil jeg ta for meg forutsetningene for forvaring som både særreaksjon og "straff", og fokusere på hva som er formålet med de strafferettslige særreaksjonene og for forvaring som straff. Dernest vil jeg gå inn på utviklingen i fastsettelsen av tidsavgrensingene (tidsramme og minstetid) i forvaringsdommene og se nærmere på implikasjonene av denne utviklingen. Så vil jeg sette søkelyset på de siste lovmessige føringene som har kommet om forvaring, for til sist å tydeliggjøre hvilke motsetninger og dilemmaer som ligger implisitt i den rådende forståelsen av forvaring.

\section{Utgangspunktet: Forvaring - en særreaksjon og "straff"}

Både Straffelovrådet og Særreaksjonsutvalget utredet den nye forvaringsbestemmelsen som én av tre særreaksjoner. Det var forvaringsreaksjonens samfunnsbeskyttende funksjon og dens tidsubestemthet som ble drøftet; man ville ha muligheten til å holde lovbrytere innesperret på ubestemt tid for å beskytte samfunnet. I Særreaksjonsutvalgets innstilling fra 1990, som de senere lovendringene i all hovedsak bygger på, understrekes det at forvaring skal være en scerreaksjon. Samtidig poengterte utvalget at "[f]orvaring skal være "straff" i straffelovens forstand" (NOU 1990: 5 s. 17). For å begrunne at forvaring skal regnes som straff henviser Særreaksjonsutvalget til Straffelovrådets utredning hvor det står:

"Rådet finner det riktigst at særreaksjonen forvaring - slik den er bygd opp i lovutkastet - blir å henregne til de sanksjoner som er "straff" i straffelovens forstand. Det er riktignok vesentlige forskjeller mellom en tidsbestemt fengselsstraff og forvaringen. Det gjelder særlig med hensyn til formålet med reaksjonen. Men det er også store likheter. Begge sanksjoner forutsetter en skyldig lovbryter, dvs. at de subjektive og objektive vilkår for straff er oppfylt, og begge sanksjoner skal primært fullbyrdes i 
anstalt under fengselsvesenet. Sett fra lovovertrederens synspunkt vil forvaringen på grunn av tidsubestemtheten lett fremstille seg som en strengere reaksjon enn en tidsbestemt fengselsstraff. Det kunne da oppfattes som en forskjønnende omskrivning å karakterisere forvaringen som noe annet enn straff." (NOU 1974: 17 s. 150)

En studie av Svendsen (2005) bekrefter Straffelovrådets uttalelse. Forvaringsdømte opplever forvaring som straff, der tidsubestemtheten - ikke å vite hvor lenge man skal sitte i fengsel - gjør at den oppleves som spesielt belastende. I følge Schaanning (2003) er imidlertid hensynet til lovovertrederens opplevelse av forvaringsreaksjonen som en begrunnelse for at forvaring også skal være straff, helt enestående i norsk strafferett.

I ekspertutvalgenes utredninger finnes det ingen klar definisjon på strafferettslig særreaksjon. Grunnvilkåret for både overføring til tvungent psykisk helsevern, overføring til tvungen omsorg og forvaring er imidlertid samfunnsbeskyttelsen, der bruken av disse reaksjonene kun kan begrunnes med et behov for å verne andres liv, helse eller frihet (se strl. §§ 39, 39 a og 39 c). I følge Andenæs mfl. (2004) er reaksjoner som bare tar sikte på å avverge en fare eller en ordensforstyrrelse ikke straff. Personer som på gjerningstidspunktet var psykotiske eller bevisstløse kan etter norsk lov ikke straffes (jf. strl. § 44), men de kan idømmes overføring til tvungent psykisk helsevern. I følge lovteksten kan heller ikke personer som er psykisk utviklingshemmet i høy grad straffes (ibid.), men de kan bli idømt overføring til tvungen omsorg. ${ }^{4}$ Hensikten med disse reaksjonene er å hindre nye lovbrudd, og det er spesialisthelsetjenesten som har det overordnede ansvaret for gjennomføringen av disse reaksjonene. Reaksjonenes varighet er ubestemt, dvs. de skal vare så lenge det er nødvendig for å opprettholde samfunnsbeskyttelsen, men en eventuell forlengelse skal vurderes hvert tredje år.

At forvaring er straff kommer først og fremst til uttrykk ved at personer som idømmes forvaring er strafferettslig ansvarlige (tilregnelige). Ser man nærmere på hva straff er, defineres straff i Norge som "et onde som staten tilføyer en lovovertreder på grunn av lovovertredelsen, i den hensikt at han skal føle det som et onde" (Rt. 1977 s. 1207, Andenæs mfl. 2004 s. 10, Slettan \& Øie 2001 s. 10). Forvaring kan bare idømmes lovbrytere som finnes skyldig i å ha begått - eller forsøkt å begå - en alvorlig (eller mindre alvorlig) voldsforbrytelse, seksualforbrytelse, frihetsberøvelse, ildspåsettelse eller en annen alvorlig forbrytelse som har krenket andres liv, helse eller frihet, eller utsatt disse rettsgodene for fare. I tillegg må det antas å være en nærliggende fare for at lovbryteren på nytt vil begå en slik forbrytelse. Denne faren må være kvalifisert og på domstidspunktet fremstå som reell. Grunnvilkåret for dom på forvaring er imidlertid at tidsbestemt straff ikke 
anses som tilstrekkelig for å verne de fundamentale rettsgodene som liv, helse eller frihet (jf. strl. § 39 c). Det er retten som skal avgjøre om risikoen for tilbakefall er så stor at vilkårene for idømming av forvaring er til stede. Det finnes imidlertid ingen sikre metoder for å vurdere fare for tilbakefall, og det er bred enighet om at usikkerheten øker jo lenger frem i tid man skal predikere (se f.eks. NOU 1990: 5 s. 105; NOU 1974: 17 s. 128, Broch 2003 s. 88, Andenæs mfl. 2004; Lehmann 2005; Johnsen 2006). Til hjelp i denne vurderingen innhenter imidlertid retten informasjon om den tiltalte enten ved personundersøkelse eller en rettspsykiatrisk erklæring (jf. strl. $\S 39 \mathrm{~d}){ }^{5}$

Ut i fra vilkårene vil man kunne si at forvaring legitimeres i det individualpreventive formålet; uskadeliggjøring, forbedring av lovbryteren og avskrekking, der uskadeliggjøringen - i form av inkapasitering i et sterkt kontroll- og sikkerhetsorientert regime - er mest fremtredende. Sammen med læren om allmennprevensjon tilhører teoriene om individualprevensjon de relative straffeteorier der tilføyelsen ondet ikke har noe egenformål, men er et middel for å hindre lovovertredelser (Andenæs mfl. 2004, Hauge 1996, Mathiesen 2007). ${ }^{6}$ I tråd med dette skal den forvaringsdømte holdes i fengsel så lenge det anses nødvendig å verne samfunnet. I et samfunn - slik som det norske - som tilstreber en mest mulig human fangebehandling, vil det imidlertid være vanskelig å kunne forsvare å sette lovbrytere i fengsel på ubestemt tid under påskudd av at de utgjør en fare for samfunnet. Lovbryterne må få en mulighet til å komme ut fra fengsel, og det er her teorien om forbedring av lovbryteren kommer inn: Under fengselsoppholdet skal det legges til rette for at den forvaringsdømte skal kunne endre seg for å redusere faren for tilbakefall. På denne måten ser man at rehabilitering og behandling er sentrale elementer $\mathrm{i}$ forvaringen. Et ønske om rehabilitering og/eller behandling vil imidlertid aldri kunne begrunne idømmelse av forvaring.

Til forskjell fra overføring til tvungent psykisk helsevern og tvungen omsorg fastsettes det noen tidsavgrensinger - tidsramme og minstetid - ved idømmelsen av en forvaringsdom. Et sentralt moment i Straffelovrådets vurdering var at fastsettelsen av en tidsramme skulle minske uvissheten som en tidsubestemt reaksjon kunne skape for lovovertrederen. Dessuten ville man sikre at påtalemyndighet og domstol prøvde grunnlaget for frihetsberøvelsen etter noen år. Likeledes mente både Straffelovrådet og Særreaksjonsutvalget at det var vurderingen av gjentakelsesfare fremover i tid som skulle være bestemmende for fastsettelsen av tidsrammen, og at det skulle suppleres med løpende vurderinger under fullbyrdelse av reaksjonen. - Men har det blitt slik?

\section{Utvikling i fastsettelsen av tidsavgrensingene}

I følge strl. § 39 e skal det ved avsigelse av en forvaringsdom alltid fastsettes en 
tidsramme som vanligvis ikke bør overstige 15 år, og ikke kan overstige 21 år. Hvis påtalemyndigheten ikke finner det forsvarlig å løslate den forvaringsdømte ved tidsrammens utløp, kan saken bringes inn for retten, og retten kan forlenge forvaringsdommen med inntil fem år om gangen. Løslatelse før tidsrammen utløper skal skje på prøve. I tillegg ilegger retten som oftest en minstetid som ikke må overskride ti år (jf. strl. § 39 e andre ledd). Minstetiden regulerer når den forvaringsdømte kan bli vurdert for prøveløslatelse. Hvis retten ikke fastsetter en minstetid kan prøveløslatelse vurderes ett år etter at dommen er rettskraftig. Opprinnelig foreslo både Straffelovrådet og Særreaksjonsutvalget at tidsrammen ved idømmelsen av forvaring ikke kunne overstige 15 år. Særreaksjonsutvalget mente at forvaringsstraffer med tidsrammer utover 15 år var formålsløst. Begrunnelsen var at fengselsstraffer på mer enn 15 år ville ivareta hensynet til samfunnsbeskyttelsen siden den straffedømte uansett ville sitte lenge i fengsel. Vedrørende minstetid foreslo Særreaksjonsutvalget at denne kunne idømmes med en øvre grense på 5 år og poengterte at "[m]instetid skal fastsettes etter en skjønnsmessig vurdering" (NOU 1990: 5 s. 118). For både Straffelovrådet og Særreaksjonsutvalget var hensynet til den allmenne rettsoppfatning en viktig begrunnelse for forslaget om minstetid, og dette ble støttet i lovproposisjonen som ble utarbeidet på grunnlag av Særreaksjonsutvalgets innstilling (Ot.ptp. nr. 87 [1993-94]). Folks tiltro til rettssystemet kunne svekkes hvis en forvaringsdømt som hadde begått en alvorlig forbrytelse, ble løslatt for tidlig.

I den politiske behandlingen av forslaget, fant flertallet $\mathrm{i}$ justiskomiteen det rimelig at det måtte være en forholdsmessighet mellom tidsbestemt fengselsstraff og forvaringsstraff: ${ }^{7}$

"[...] det ikke kan være snakk om at særreaksjonen blir en mildere straff enn det som ville blitt gitt for et tilfelle hvor det ikke forelå fare for gjentakelse. Etter dette flertallets oppfatning burde det derfor alltid fastsettes en mistetid for særreaksjonens lengde." (Innst.O. nr. 34 (1996-1997) kap. 8.2) [...] "Etter flertallets syn ville det kunne bringe hele instituttet med forvaring i vanry dersom eksempelvis en som tidligere er dømt for drap og blir dømt for drap igjen kan ilegges forvaring som er vesentlig kortere enn den tiden en annen som blir dømt for en tilsvarende forbrytelse må sone i fengsel før prøveløslatelse kan skje.” (Innst.O. nr. 34 (1996-1997) kap 8.6).

Flertallet foreslo derfor å heve tidsrammen til 21 år slik at den ble like lang som maksimal fengselsstraff. Det samme flertallet foreslo også å heve den maksimale minstetiden til ti år, men ga ingen begrunnelse for hvorfor akkurat denne 
grensen ble valgt. Likeledes foreslo dette flertallet å endre ordlyden i lovforslaget fra at minstetid kan idømmes til bør idømmes. Disse endringene kom inn i den endelige lovbestemmelsen (jf. strl. § 39 e). Med henvisning til justiskomiteens poengtering av forholdsmessighet mellom forvaring og alternativ tidsbestemt straff skriver Riksadvokaten at det bør "[...] regulært påstås en minstetid svarende til forventet prøveløslatelse [...]" (Rundskriv nr. 4/2001 s. 10-11).

Til tross for disse føringene om forholdsmessighet uttalte førstvoterende høyesterettsdommer følgende om fastsettelsen av tidsrammen i en av de første forvaringssakene som ble behandlet i Høyesterett (Rt. 2002 s. 1667):

"Etter min mening kan det ikke være riktig å prøve å komme frem til et bestemt forhold mellom tidsramme og alternativ fengselsstraff som skal gjelde generelt. Forholdstallet bør kunne variere etter hvor sikkert retten mener å kunne vurdere den domfeltes farlighet mange år fremover, og det kan også ha betydning om det er tale om en særlig kort eller en særlig lang alternativ fengselsstraff." (s. 1671-72)

I tråd med dette mener Rieber-Mohn (2003) at det ikke primært skal ses hen til forbrytelsens grovhet som det viktigste momentet i fastsettelsen av tidsrammen, men til vurderingen av gjentakelsesfaren. Dermed knyttes også forvaringen til eksistensgrunnlaget, nemlig dens tidsubestemthet.

Men selv om Høyesterett har uttalt at det er vurderingen av gjentakelsesfare og ikke forholdsmessigheten med alternativ tidsbestemt straff som skal være bestemmende for utmålingen av tidsrammen, synes det likevel som om dette ikke er praksis. Praksis ser heller ut til å følge en dissens i Høyesterett (Rt. 2002 s. 889) der én av dommerne mente at i den aktuelle saken burde tidsrammen settes lik alternativ fengselsstraff. Førstvoterende mente at tidsrammen skulle settes til 15 år - seks år lengre enn alternativ fengselsstraff. Rettspraksis viser at $\mathrm{i}$ de aller fleste forvaringsdommene med tidsramme under åtte år er tidsrammen satt litt lengre enn alternativ fengselsstraff. I to høyesterettsdommer, Rt. $2002 \mathrm{~s}$. 1673 og Rt. 2008 s. 1403, er dette begrunnet med henholdsvis fradrag av tid i varetekt og behandlingstid. En rimelig tolkning av sitatet ovenfor (fra Rt. 2002 s. 1667) kan imidlertid være at det er naturlig å sette en tidsramme som er litt lengre enn den alternative tidsbestemte straffen når sistnevnte er forholdvis kort. En gjennomgang av forvaringsdommene med tidsrammer under åtte år viser også at fastsettelsen av tidsrammen sjelden begrunnes særskilt utover en indirekte referanse til samfunnsbeskyttelsen. I dommer med tidsramme fra og med åtte til 21 år, fastsettes tidsrammen tilnærmet lik lengden på den alternative fengselsstraffen. ${ }^{8}$ Angående minstetid settes denne tilnærmet lik $2 / 3$ av alternativ tidsbestemt straff, 
dvs. når prøveløslatelse kunne funnet sted. ${ }^{9}$ For eksempel sies det i Rt. $2002 \mathrm{~s}$. 1667: "Minstetiden bør settes med utgangspunkt $\mathrm{i}$ et anslag over når prøveløslatelse etter en fengselsstraff ville kunne skjedd, jf. Innst.O. nr. 34 for 1996-97 s. 22 og Rt. 2002 s. 889 på side 894-5” (s. 1671). Slik rettspraksis har utviklet seg synes det som vurderingen av gjentakelsesfare $i$ all hovedsak benyttes i overveielsen om vilkårene for å idømme forvaringsstraff er til stede, og om det skal idømmes forvaring, men i mindre grad til å utmåle tidsavgrensingene. Man kan da spørre: Hva blir implikasjonene for forståelsen av forvaring når det ikke er farevurderingene, men strafferammen og derved grovheten i de begåtte lovbruddene (det er som oftest flere) som blir førende for hvilke tidsavgrensinger som settes?

\section{Rettferdighet}

Ved å ta utgangspunkt i rettspraksis for tilsvarende forbrytelser ved fastsettelsen av tidsavgrensingene i forvaringsreaksjonen, sikrer man at forvaringsdømte ikke får en 'mildere' straff enn dem som får en ordinær fengselsstraff. Mottakerne av straffen, uansett om de idømmes forvaring eller ubetinget fengsel, stilles på denne måten i utgangspunktet likt, og man oppnår det såkalte prinsippet om fordelingsrettferdighet (jf. Eckhoff 1971, se også Andenæs mfl. 2004 og Mathiesen 2007). Dette er ikke primært av hensyn til at de som dømmes skal oppleve straffene som rettferdige, men av hensyn til den allmenne rettsoppfatning. I følge Andenæs mfl. (2004) er den allmenne rettsoppfatning en forenklet antakelse om folks meninger som ofte i realiteten er usikre og sprikende i mange retninger (se f.eks. Balvig 2006, Mathiesen 2007, Olaussen 2010, Ryssdal 2007), men der gjengjeldelsesog soningsforestillinger spiller en betydelig rolle. Det er dette som synes å ligge til grunn for justiskomiteens antakelse om at forvaringsinstituttet kan bringes i vanry hvis det ikke er forholdmessighet mellom idømmelse av forvaring og vanlig fengselsstraff. Det samme resonnementet synes også å ligge til grunn for en utredningsgruppe som anbefaler å heve den øvre grense for minstetid fra ti til 14 år når tidsrammen som idømmes er over 15 år. ${ }^{10}$ Etter dagens lovbestemmelse kan det ved en forvaringsdom med tidsramme på 21 år gis prøveløslatelse etter ti år, mens det ved en ordinær fengselsstraff på 21 år ikke kan gis prøveløslatelse før etter 14 år. Ved å gi retten anledning til å idømme minstetid opp til 14 år er det mulig å sikre at det ved en forvaringsdom gis et like langt fengselsopphold som ved en fengselsdom. På denne måten mener utredningsgruppen at man kan unngå å komme i strid med folks rettsfølelse, noe man lett kan gjøre ved tidlig løslatelse av forvaringsdømte.

Eckhoff (1971) utviklet begrepet likevektsrettferdighet for å betegne prinsippet om forholdsmessighet mellom forbrytelse og straff. At likevektsrettferdigheten synes å ha blitt et prinsipp for fastsettelsen av tidsavgrensinger ved idømmelsen av 
forvaring, kan også komme av at forvaring er blitt benyttet i saker som virker sterkt opprørende på folk flest, f.eks. i grove seksuelle overgrep mot små barn. I følge Andenæs mfl. (2004: 89) synes det som man ved straffeskjerpelsene for seksuelle overgrep mot barn i 2000 ikke har "[...] angitt hensynet til almenprevensjonen som begrunnelse, men utelukkende begrunnet straffeskjerpelsene i hensynet til proporsjonalitet". For lave tidsavgrensinger mht. forvaringsreaksjonen i saker som omhandler seksuelle overgrep mot barn kan vekke en sterk moralsk indignasjon, slik som i saken mot den såkalte 'lommemannen'. Han ble tiltalt for 68 overgrep mot 66 gutter, og det ble lagt ned påstand om forvaring med en tidsramme på ni år og en minstetid på seks år. I en kommentar i Aftenposten 08.04.10, mente journalisten at denne straffepåstanden var for lav og skrev følgende:

"Etter at statsadvokaten i sin prosedyre på en overbevisende måte argumenterte for streng straff, kom påstanden nærmest som en flau bris. Sannsynligvis ville ikke så mange ha reagert om han hadde høynet forvaringstiden med to eller tre år."

Etter at dommen falt i tingretten 14. juni 2010, der aktoratets påstand ble tatt til følge, ble det en debatt i mediene om dommen var streng eller ikke. I prinsippet er denne diskusjonen lite relevant fordi forvaring er en streng reaksjon i seg selv: Den forvaringsdømte lever i en konstant uvisshet om hvor lenge reaksjonen vil vare, og vedkommende kan risikere å bli sittende i fengsel resten av livet. Men siden tidsavgrensingene i dommen avspeiler de begåtte forbrytelsenes grovhet og klandreverdighet, er det med utgangspunkt i tidsramme og minstetid diskusjonen om streng eller mild straff oppstår. Det er særlig tidsrammen som blir poengtert i media, i f.eks. overskrifter som "Ni års forvaring i Lommemann-saken" (Aftenposten nettavisen 14.06.10), "Påstand om 13 og 14 års forvaring" (nrk.no 17.02.11) eller "Hovedtiltalte fikk 11 og 12 års forvaring" (Adressa nettavisen 18.02.11). Forvaringens tidsubestemthet blir i forhold til dette ofte betraktet som en mulighet til å straffe ekstra hardt, og følgende sitat er hentet fra VG nettavisen 14.06.10: "En forvaringsdom betyr at retten mener en tidsbestemt fengselsstraff ikke er streng nok når $[\mathrm{XX}]$ skal dømmes." Dette synes å stemme dårlig overens med Høyesteretts oppfatning av forvaring, der førstvoterende i den såkalte 'NOKAS-saken' uttalte følgende:

"Jeg understreker først at formålet med forvaring ikke er å ramme de mest alvorlige forbrytelser med en særlig streng straff. Forvaring er en særforholdsregel overfor spesielt farlige lovbrytere for å beskytte samfunnet mot at de begår nye farlige forbrytelser i fremtiden." (Rt. 2007 s. 1056, sitat hentet fra s. 1073) 
Høyesterett understreker dermed at det er hensynet til samfunnsvernet som skal begrunne avgjørelsen om å idømme forvaring, ikke mulighetene til å idømme en særlig streng straff. Samtidig har det skjedd en redefinering av forvaringen som kan synes å rokke ved det opprinnelige formålet med reaksjonen.

\section{Fra "straff" til lovens strengeste straff}

Det er rimelig å anta at hensynet til rettferdighet samt tilnærmingen av forholdsmessighet mellom tidsavgrensingene i forvaringsreaksjonen og utmålingen av alternativ tidsbestemt fengselsstraff, har medvirket til at forvaring i dag ikke lenger er å regne som en særreaksjon. I arbeidet med ny straffelov er forvaring blitt utelukket fra betegnelsen særreaksjon. Dette ble begrunnet slik:

"Forvaring er en tidsubestemt frihetsstraff for særlig farlige tilregnelige lovbrytere. [...] Forvaringsstraff omtales gjerne som en strafferettslig særreaksjon. I det følgende vil departementet reservere betegnelsen 'særreaksjon' til de strafferettslige særreaksjonene overfor utilregnelige lovbrytere; overføring til tvungent psykisk helsevern og tvungen omsorg". (Ot. prp. nr. 90 [2003-2004] s. 274)

Både i gjeldende straffelov ( $(15)$ og i ny straffelov (§ 29) står forvaring oppført som straff. I gjeldende straffelov omtales imidlertid forvaringen sammen med de to andre særreaksjonene, i $\S 39 \mathrm{flg}$. der $\S \S 39 \mathrm{c}-\mathrm{h}$ omhandler forvaring. I ny straffelov derimot er forvaring skilt fra de to andre særreaksjonene og omtales i et eget kapittel - kapittel 7 ( $\S 40-47$ ), mens overføring til tvungent psykisk helsevern og tvungen omsorg omtales i kapittel 12 (§§ 62-65). I forbindelse med endringer i straffeloven og delvis ikraftsetting av ny straffelov er det blitt foretatt endringer i straffeloven, straffeprosessloven og straffegjennomføringsloven ved at forvaring er skilt ut fra særreaksjonsbegrepet. ${ }^{11}$ For eksempel lyder straffelovens $\S 26$ etter endringen som følger: "De nærmere reglene om gjennomføring av fengselsstraff, samfunnsstraff, strafferettslige særreaksjoner og forvaring gis ved særskilt lov". Likeledes lyder nå Straffegjennomføringslovens $\S 1$ : "Denne loven gjelder for gjennomføring av fengselsstraff, strafferettslige særreaksjoner, forvaring, samfunnsstraff og varetektsfengsling og for gjennomføring av andre reaksjoner når det er særskilt bestemt i lov". Forskriften som regulerer gjennomføring av forvaring heter imidlertid fremdeles Forskrift om gjennomføring av sarreaksjonen forvaring (2004.03.05 $\mathrm{nr} 0481$ ).

Mens tidsrammen, som tidligere påpekt, opprinnelig ble foreslått av hensyn til den forvaringsdømte for å minske uvissheten i den tidsubestemte reaksjonen, har hevingen av maksimum tidsramme til 21 år utelukkende blitt begrunnet med pro- 
porsjonalitetshensyn og forestillinger om rettferdig gjengjeldelse. Dette har derfor medvirket til at forvaring klart fremstår som lovens strengeste straff i Norge (se også Johnsen \& Storvik 2006). Dette poengteres også i høringsnotatet Ny straffelov: Forslag til generelle regler om formildende og skjerpende omstendigheter $i$ straffutmålingen, og om skjerping av reaksjonen for de alvorligste lovbruddene (domstolsbestemt prøveløslatelse) (august 2005) der justisdepartementet med henvisning til justiskomiteens innstilling vedrørende proporsjonalitet hevder at "[f]orvaring må anses for å være lovens strengeste reaksjon for grov og ordinær kriminalitet" (s. 31). Departementet viser videre til at en forvaringsdom kan forlenges. Det påpekes imidlertid at dilemmaet kommer i den andre enden. En forvaringsdømt kan prøveløslates tidligere og dermed få en kortere frihetsberøvelse enn ved en tidsbestemt fengselsstraff, fordi vedkommende etter dagens lovverk kan prøveløslates etter ti år. Departementet ber om høringsinstansenes syn på om det bør tilstrebes en "rangmessig harmoni" mellom forvaring og tidsbestemt straff. Som jeg har vist til tidligere, er dette nå foreslått av utredningsgruppen som har etterkontrollert særreaksjonene. Men hva kan retten vite om gjentakelsesfaren ti14 år frem i tid?

\section{Vurdering av gjentakelsesfare og prøveløslatelse}

I justiskomiteens behandling av det første lovforslaget for forvaringsordningen (Ot.prp. nr. 87 [1993-94]) fant flertallet det "[...] mest hensiktsmessig å foreta en farlighetsbedømmelse på domstidspunktet, men forutsetter som i forslaget at det også suppleres med en løpende vurdering under fullbyrdelsen av særreaksjonen" (Innst.O. nr. 34 (1996-1997) kap. 8.3). ${ }^{12}$

I løpet av gjennomføringen av en forvaringsdom vurderes gjentakelsesfaren jevnlig med tanke på innvilgelse av permisjoner, overføring til fengsler med lavere sikkerhetsnivå etc. Denne farevurderingen foretas imidlertid av kriminalomsorgen og ikke av retten. Selv om kriminalomsorgen i perioden før oppnådd minstetid ville kunne vurdere risikoen for nye lovbrudd som så lav at det kunne vært forsvarlig å prøveløslate vedkommende, må han/hun likevel være fengslet frem til oppnådd minstetid. Justiskomiteens forutsatte imidlertid at det er retten som skal foreta en løpende farevurdering under fullbyrdelsen med tanke på prøveløslatelse. Både Særreaksjonsutvalget og departementet mente at en løpende farevurdering under fullbyrdelsen med tanke på prøveløslatelse var en viktig forutsetning for et tilstrekkelig etisk grunnlag for forvaringen. Som i dag visste man den gang forslaget ble laget, at farevurderinger langt frem i tid er svært usikre. Dette var også et viktig argument for å holde tidsavgrensingene i forvaringsdommen forholdsvis lave både hos Straffelovrådet og Særreaksjonsutvalget. Etter dagens lovbestemmelse kan det gå opptil ti år mellom påtalemyndighetens og domstolens vurdering 
av gjentakelsesfare på domstidspunktet og ved oppnådd minstetid. Denne perioden økes til 14 år hvis prinsippet om rettferdighet gjennomføres fullt ut. Dette kan synes motstridende i forhold til kunnskapen man har om vurderinger av gjentakelsesfare og den politiske føringen om løpende farevurdering. Dessuten kan man spørre: Hvordan står denne økningen i forhold til det etiske grunnlaget for forvaringen som opprinnelig ble lagt til grunn?

Om ikke lenge, mest sannsynlig i løpet av dette eller neste år, vil prøveløslatelsessakene komme fra de forvaringsdømte som har tidsrammer på over 15 år og minstetider på ti år. I disse sakene vil kriminalomsorgen, påtalemyndigheten og retten måtte ta stilling til prøveløslatelse av forvaringsdømte på et tidligere tidspunkt enn om de hadde fătt tidsbestemt straff. Det spesielle ved disse sakene er at personene som søker prøveløslatelse er dømt for svært grove lovbrudd, der flere av sakene har vært mye omtalt i media og har vakt stor moralsk indignasjon og fordømmelse i befolkningen - f.eks. Baneheiasaken. ${ }^{13}$ Egentlig er vilkårene for prøveløslatelse klare, for det eneste som kan begrunne et avslag på en søknad om prøveløslatelse fra en forvaringsdømt, er samfunnsbeskyttelsen - at sannsynligheten for gjentakelse av alvorlige lovbrudd er så stor at det ikke er forsvarlig å løslate vedkommende. Samtidig er hensyn til rettferdighet og den allmenne rettsoppfatningen momenter som mest sannsynlig vil komme i betraktning, og man kan tenke seg at med betoningen av forvaring som straff kan det bli vanskelig å forsvare prøveløslatelse av en forvaringsdømt tidligere enn om vedkommende hadde fått en ordinær fengselsstraff. Allerede nå har man sett eksempler på at retten og politikere er på kollisjonskurs når det gjelder spørsmålet om prøveløslatelse fra forvaring. Trolig vil sakene som nå kommer, få stor betydning for den videre utviklingen av forvaringsordningen.

\section{Ett skritt frem eller ett tilbake?}

En del av bakgrunnen for å innføre den nye forvaringsordningen var et ønske om å avskaffe det dobbeltsporede systemet med straff og sikring. For tilregnelige lovbrytere som fikk både fengselsstraff og sikring, fungerte fengselsdommen som straff for hva man hadde gjort, mens sikring skulle beskytte samfunnet mot ny kriminalitet. Sikring ble juridisk sett ikke definert som straff, men den ble opplevd som det: For de aller fleste sikringsdømte førte det ikke til noen innholdsmessig forskjell å sitte i fengsel på ubetinget dom eller sikring på Ila, Bredveit eller et annet fengsel. For å imøtegå kritikken om 'dobbel straff' ble forvaring innført. Forvaring skulle begrunnes med samfunnsbeskyttelse, og det var behovet for samfunnsbeskyttelse som skulle være avgjørende for hvor lenge en forvaringsdømt skulle holdes innesperret i fengsel. 
Nå, snart ti år etter at lovbestemmelsen trådte i kraft, kan det imidlertid virke som krav om rettferdighetshensyn har blitt den mest sentrale begrunnelsen for hvor lenge forvaringsstraffen skal vare. Det synes ikke som om man lenger er så bekymret for at forvaringsdømte sitter lengre i fengsel enn det som kanskje ville vært nødvendig ut i fra hensynet til samfunnsvernet. Den rådende tankegangen virker å være å kunne straffe den som dømmes til forvaring, og da minst like hardt som om han/hun hadde fått en ubetinget straff. Etter at vedkommende har oppnådd minstetid (altså sonet like lenge som om han/hun hadde fătt en tidsbestemt fengselsstraff og bli løslatt på $2 / 3$ tid) kan man vurdere løslatelse ut fra en vurdering av gjentakelsesfaren. Og man kan da spørre: Er det i praksis blitt noen forskjell på forvaring og den tidligere ordningen med ubetinget fengselstraff og sikring der man normalt også sonet $2 / 3$ av den ubetingede straffen før man gikk over på sikring? Som under sikringsinstituttet kan dette tolkes som at en forvaringsdømt først soner straffen for det han/hun har gjort, deretter skal det vurderes om risikoen for gjentakelse fortsatt er så stor at det er forsvarlig å løslate vedkommende. Det skal imidlertid presiseres at ved innføringen av domstolsbehandling av prøveløslatelsesspørsmålet for forvaringsdømte, er rettssikkerheten blitt forbedret. Under sikringssystemet var prøveløslatelsen en administrativ vurdering som ble foretatt av fengselsvesenet. Likevel var muligens sikringssystemet mer oversiktlig og lettere å forholde seg til sammenlignet med den nåværende forvaringsordningen. Som Schanning (2003 s. 6) skriver: "Det var så ryddig og ga tydelig beskjed om hvilke begrunnelser man først og fremst la vekt på for de to reaksjonsformene: Først skulle det gjøre vondt (straff), så skulle man bare beskytte (sikring)." Nå skal man straffe for å beskytte. En sentral kritikk mot sikringssystemet var at sikringsdømte ble 'straffet for ugjort gjerning' - men er ikke denne kritikken blitt enda mer treffende for forvaringen?

Selv om forvaring ikke lenger defineres som en særreaksjon, vil den likevel fremstå med en særreaksjons rasjonale så lenge vilkårene for idømmelse av forvaring består. På en måte vil man kanskje derfor kunne si at forvaringsreaksjonen i dag fremtrer med en dobbelhet som er blitt enda klarere enn før: Den er både straff og samfunnsbeskyttelse. Denne dobbelheten fører logisk sett til noen spørsmål: Vil man begge deler - både straffe og beskytte, eller er dette et uttrykk for at man ikke helt vet hva man vil? Videre kan det spørres: Hva er hensikten med en ensidig betraktning av forvaring som straff? Vil man, uten å berøre det maksimale straffenivået på 21 år, ha en straff der man har anledning til å straffe enda hardere? Uansett - forvaringsstraffen står allment frem i offentligheten med to rasjonaliteter som er problematisk for rettssystemet, og som står i fare for å bli uangripelig. Samme hva man argumenterer for - straff og/eller samfunnsbeskyttelse - vil man kunne vinne frem. 


\section{Litteratur}

Adressa nettavisen 18.02.11

Aftenposten nettavisen 14.06.10

Aftenposten 08.04.10

Almindelig borgelig Straffelov 22. mai 1902 Nr. 10 (Straffeloven)

Andenæs, J., Matningsdal, M. og Rieber-Mohn, G. F. (2004). Alminnelig strafferett. Oslo: Universitetsforlaget, 5. utgave

Balvig, F. (2006). Danskernes syn på straf. Advokatsamfundet

Broch, S. (2003). Forvaring. En scerreaksjon basert på farevurderinger - vil de gjøre det igjen? Hovedoppgave ved Juridisk fakultet, Universitetet i Oslo

Delvis ikraftsetjing av lov 21. desember 2005 nr. 131 om oppheving av lausgjengarlova og om endringar i straffelova o.a. (eige straffebod mot vald i nære relasjoner o.a.) og delvis ikraftsetjing av lov 20. mai 2005 Nr. 28 om straff (straffeloven)

Eckhoff, T. (1971). Rettferdighet. Oslo: Universitetsforlaget

Etterkontroll av reglene om strafferettslig utilregnelighet, strafferettslige scerreaksjoner og forvaring (2008). Rapport fra utredningsgruppe oppnevnt av Justis- og politidepartementet 18. mai 2006

Forskrift om gjennomføring av scerreaksjonen forvaring (2004.03.05 nr 0481)

Hauge, R. (1996). Straffens begrunnelser. Oslo: Universitetsforlaget

Innst.O. nr. 113 (2000-2001) Innstilling fra justiskomiteen om lov om endringer $i$ straffeloven og $i$ enkelte andre lover (endringer og ikraftsetting av strafferettslige utilregnelighetsregler og scerreaksjoner samt endringer i straffeloven $\$ 238$ og $\$ 239)$

Innst.O. nr. 34 (1996-1997) Innstilling fra justiskomiteen om lov om endringer $i$ straffeloven m.v. (strafferettslig utilregnelighetsregler og scerreaksjoner)

Johnsen, B. (2006). "Forvaring - et barn av sin tid?". Materialisten, vol. 34, nr. 4, s. 53-89

Johnsen, B. \& Storvik, B. L. (2006). "Forvaring og utviklingen for perioden $2002-$ 2006". Nordisk tidsskrift for kriminalvidenskap, vol 93, nr. 1, s. 51-67

Lehmann, K. (2005). Dømt til forvaring: Kritiske synspunkter på en "ny og bedre" strafferettslig sœerreaksjon. Stensilserie (Juss-buss), nr. 102

Lov om oppheving av lausgjengarlova og om endringar i straffelova o.a. (eige straffebod mot vald i nære relasjoner o.a.) 21. desember 2005 Nr. 131

Lov om straff 20. mai 2005 Nr. 28 (straffeloven). (Loven er ennå ikke trådt i kraft.)

Lov om rettergangsmåten i straffesaker 22. mai 1981 Nr. 25 (Straffeprosessloven)

Mathiesen, T. (2007). Kan fengsel forsvares? Oslo: Pax forlag A/S

NOU 1990: 5 Strafferettslige utilregnelighetsregler og scerreaksjoner 
NOU 1974: 17 Strafferettslig utilregnelighet og strafferettslige sarreaksjoner nrk.no 17.02.11

Ny straffelov: Forslag til generelle regler om formidlende og skjerpende omstendigheter i straffutmålingen, og om skjerping av reaksjonen for de alvorligste lovbruddene (domstolsbestemt prøveløslatelse). Høringsnotat, Justisdepartementet, Lovavdelingen, august 2005

Olaussen, L. P. (2010). Straffenivået og folks holdninger til straff $i$ Norge. Universitetet i Oslo: Institutt for kriminologi og rettssosiologi

Ot.prp. nr. 90 (2003-2004) Om lov om straff (straffeloven)

Ot.prp. nr. 46 (2000-2001) Om lov om endringer $i$ straffeloven og $i$ enkelte andre lover (endring og ikraftsetting av strafferettslige utilregnelighetsregler og sarreaksjoner samt endringer $i$ straffeloven $\$ \$ 238$ og 239)

Ot.ptp. nr. 87 (1993-94) Om lov om endringer i straffeloven $m v$ (strafferettslige utilregnelighetsregler og scerreaksjoner)

Rieber-Mohn, G. F. (2003). "Forvaring - en strafferettslig særreaksjon I og II". Juristkontakt, nr. 4 s. $36-40$ og nr. 5 s. 35-39

Riksadvokaten (desember 2001). Rundskriv nr. 4/2001

Ryssdal, A. (2007). Den allmenne rettsfølelse - en veiviser eller villeder $i$ strafferetten, Advokatforeningens årstale 2007.

http://www.advokatforeningen.no/PageFiles/4866/Arstalen\%202007.pdf

Schaanning, E. (2003). "Forvaring og rettferdighet". Kromnytt, nr. 2, s. 5-11

Slettan, S. \& Øie, T. M. (2001). Forbrytelse og straff. Bind I: Innføring $i$ strafferett. Oslo: Universitetsforlaget

Straffegjennomføring etter lov av 18. mai $2001 \mathrm{nr} .21$

Svendsen, M. (2005). Forvaringsfangene forteller - En kvalitativ studie av den nye sarreaksjonen forvaring. Masteroppgave i rettssosiologi, Institutt for kriminologi og rettsosiologi, Juridisk fakultet, Universitetet i Oslo

VG nettavisen 14.06.10

\section{Domsregister}

Rt. 2008 s. 1403

Rt. 2007 s. 1056

Rt. 2007 s. 183

Rt. 2005 s. 289

Rt. 2004 s. 541

Rt. 2003 s. 1778

Rt. 2003 s. 312

Rt. 2002 s. 1673 
Rt. 2002 s. 1667

Rt. 2002 s. 889

Rt. 1977 s. 1207

1 Jeg vil takke Yngve Hammerlin, Thomas Mathiesen og Birgitte Storvik for deres støtte og nyttige kommentarer underveis i arbeidet med denne artikkelen.

2 Den gamle forvaringsbestemmelsen var lite brukt, og den siste forvaringsdommen etter den gamle ordningen ble avsagt i 1963. Lovbestemmelsen ble imidlertid først opphevet når de nye lovbestemmelsene om særreaksjonene trådte i kraft.

3 Se Ot.ptp. nr. 87 (1993-94) Om lov om endringer $i$ straffeloven $m v$ (strafferettslige utilregnelighetsregler og scerreaksjoner); Innst.O. nr. 34 (1996-1997) Innstilling fra justiskomiteen om lov om endringer $i$ straffeloven m.v. (strafferettslig utilregnelighetsregler og scerreaksjoner); Ot.prp. nr. 46 (2000-2001) Om lov om endringer $i$ straffeloven og $i$ enkelte andre lover (endring og ikraftsetting av strafferettslige utilregnelighetsregler og sarreaksjoner samt endringer i straffeloven $\S \S 238$ og 239); Innst.O. nr. 113 (2000-2001) Innstilling fra justiskomiteen om lov om endringer $i$ straffeloven og $i$ enkelte andre lover (endringer og ikraftsetting av strafferettslige utilregnelighetsregler og sarreaksjoner samt endringer i straffeloven $\$ 238$ og § 239).

4 I utgangspunktet anses personer med IQ under 55 som høygradlig psykisk utviklingshemmet. I tillegg skal imidlertid personlighet, sosial fungering, evne til abstrakt tenkning mv. vurderes sammen med fungering i bomiljø, arbeidsplass osv. (se NOU 1990: 5 s. 52 og Etterkontroll av reglene om strafferettslig utilregnelighet, strafferettslige sarreaksjoner og forvaring s. 175).

5 Bruk av rettspsykiatriske sakkyndige er en debatt jeg velger ikke å ta opp i denne artikkelen da dette ligger litt utenfor artikkelens hovedtema. Se imidlertid de nevnte referansene for mer om dette.

En personundersøkelse har som formål å skaffe opplysninger om den siktedes personlighet, livsforhold og fremtidsmuligheter til bruk for avgjørelse i en rettssak. Undersøkelsen foretas som regel i regi av kriminalomsorg i frihet (jf. strpl. kap. 13).

6 Med allmennprevensjon menes "forhindring av at andre enn den straffede selv begår kriminelle handlinger" (Mathiesen 2007 s. 36).

7 Flertallet besto av alle unntatt medlemmene fra Arbeiderpartiet og Sosialistisk Venstreparti.

8 Se f.eks. Rt. 2003 s. 312: Tidsramme 13 år, tidsbestemt straff 11-12 år. Rt. 2003 s. 1778: Tidsramme 21 år, tidsbestemt straff det samme. Rt. 2004 s. 541: Tidsramme 8 år, det samme som tidsbestemt straff. Rt. 2005 s. 289: Tidsramme15 år, tidsbestemt straff 14 år. Rt. 2007 s. 183: Tidsramme 12 år, det samme som tidsbestemt straff. Rt. 2007 s. 1056: Tidsramme 16 år, det samme som tidsbestemt straff.

9 Se f.eks. Rt. 2002 s. 889, Rt. 2002 s. 1667, Rt. 2002 s. 1673 og Rt. 2003 s. 312.

10 Denne utredningsgruppen ble i 2006 oppnevnt av justisdepartementet for å foreta etterkontroll av særreaksjonene. I 2008 leverte gruppen rapporten Etterkontroll av reglene om strafferettslig utilregnelighet, strafferettslige scerreaksjoner og forvaring.

11 Se 'Lov om oppheving av lausgjengarlova og om endringar i straffelova o.a. (eige straffebod mot vald i nære relasjoner o.a.) 21. desember 2005 Nr. 131' og 'Delvis ikraftsetjing av lov 21. desember $2005 \mathrm{nr}$. $131 \mathrm{om}$ oppheving av lausgjengarlova og om endringar i straffelova o.a. (eige straffebod mot vald i nære relasjoner o.a.) og delvis ikraftsetjing av lov 20. mai $2005 \mathrm{Nr}$. 28 om straff (straffeloven)'.

12 Flertallet besto av alle unntatt medlemmene fra Sosialistisk venstreparti.

13 I denne saken ble to menn dømt for mishandling og drap på to jenter. Den ene fikk en forvaringsdom med tidsramme på 21 år og minstetid på 10 år. 